\title{
Perceived Influence of Socio-Economic Infrastructure on Vocational Skills Acquisition and Practice Among Youths in Bonny Local Government Area
}

\author{
Nnodim, A.U. \& Allison, Matilda T. \\ Department of Vocational and Technology Education, Rivers State University, Port Harcourt, Nigeria \\ Email: ukachi68@gmail.com
}

\begin{abstract}
The study was conducted to investigate the perceived influence of socio-economic infrastructure on vocational skills acquisition and practice among rural youths in Bonny Local Government Area, Rivers State. Three objectives, three research questions and three hypotheses guided the study. The total population of the study was 78,373 rural youths while the sample size was 398 youths sampled from the population using Taro Yeman sample determination model. A structured questionnaire was used to gather data for the study. Data were analyzed using mean and standard deviation, while z-test was used to test the hypotheses at 0.05 level of significance. The findings revealed that youths in Bonny Local Government Area agreed that they were exposed to varied vocational skills training. Also, the respondents agreed that transportation influences their acquisition and practice of vocational skills, and finally, the youths agreed that electricity influences their vocational skills acquisition and practice amongst other. It was then recommended that government should provide more training centres for youths, employment should not be on paper and pen qualifications alone but also on skills acquisition related to the job areas.
\end{abstract}

Keywords: influence, socio-economic, infrastructure, vocation, skills, acquisition.

\section{Introduction}

Vocational skills acquisition and practice now has taken the centre stage in the social and economic development of a nation. In line with this statement, Lawal (2014) opined that for a country to advance socially, economically and technologically, its citizens must be creative and productive, with a majority becoming job creators rather than job seekers, Lawal therefore concluded by emphasizing that optimum attention and recognition must be given to vocational and technical education in Nigeria, if the country would attain great achievements. According to a report by Industrial Training Fund (2014), the acquisition of relevant skills by citizens of nations is stressed as one of the critical factors for industrial and by extension economic development. Igwe and Oragwu (2014) stated that vocational skills acquisition provides the strategies for the effective training of individual in various skills areas. Igwe and Oragwu further stated that vocational skills are knowlwde indices and attitudinal development of potential abilities to perform a given tax according to specification. Gaiba (2010) confirmed that vocational skills contribute greatly towards creating new jobs, wealth, poverty eradication and income generation for both Government and individuals, especially those in rural areas. Through vocational skills, a pool of people such as rural youths could be equipped with skills and technical knowledge on how to manage small and medium scale industries.

Skill is observable competence to perform a learned behavior regarding the relationship between mental activity and body movements (Thomas \& Amaechi, 2016). This means that to posses a skill is to demonstrate that habit of acting, thinking and behaving in a specific activity, 
in such a way that the process becomes natural to the individual through repetition. Skill could be seen as a kind of education acquired without emphasis on white collar jobs, while acquisition according to Thomas and Amaechi is the act of setting new knowledge and skills that can be transferable from one person to another. Ezeji and Okorie in Anaele (2018) noting the importance of skills acquisition in national development averred that the nation's socioeconomic problems will be ameliorated when people are given adequate vocational skill. Vocation as defined by Anaele (2018) is an occupation or trade which is practiced by an individual in order to earn a living. While vocational skills is defined by Ojingwa (2018) as the process of making superlative output and the general characteristics of one's behavior in a given field. Vocational skills are skills that focuses on specific trade with a hands-on approach, in areas such as agriculture, health or construction as well as general employment skills (Revermann, 2015). Human Capital Theory in Inyang and Agwadu (2017) best explains vocational skills acquisition as the sure therapy to check raging poverty as well as stimulate rapid socio-economic development of the rural poor.

Kabiru (2016) defined infrastructure as the basic facilities that are essential for the development of a nation. Kabiru described infrastructure as the final consumption item by households and as intermediate consumption item for firms. World Development Report in Goel (2002) categorized infrastructure into economic and social infrastructure. Economic infrastructure according to World Development Report includes services such as electricity, transportation, water system, communication, irrigation, energy, financial institution amongst others while social infrastructure includes services such as hospitals, schools, housing, correctional facilities amongst others. Availability of infrastructures be it social or economic according to World Bank Report in Goel (2002) significantly influences development, especially in rural communities. Also, infrastructure provision enhances the production and distribution network of key sectors in the economy as well as promotes overall economic growth.

International Labour Organization in Nwafor (2018) described youth as an individual with full life promise, energy and aspiration between childhood and adulthood. Youths need to develop and acquire necessary skills to enable them meet the challenges of particular jobs, aspirations as well as prepare for higher responsibilities and for future needs. Okoye (2017) noted that the solution to youth unemployment in Nigeria is vocational sills acquisition and practice. When youths are skillful in life, the chances of associating themselves with social vices will not be there. Dada (2007) states that practical work contributes in molding the mind of youths. According to Ekesionye and Okolo (2012), youth empowerment and their full participation is the basis of equity in all spheres of society such as access to power, land, credit are fundamental for the achievement of equality, peace and societal development. Empowerment of youths could mean encouraging youths to be self-reliant, economically independent, having positive selfesteem, generating confidence to face any difficult situation and incite active participation in various socio-economic and political endeavors. The benefits derived from any empowerment programme must not only be relevant to the needs of the intended beneficiaries but efforts must be made to ensure the target population is also able to retain the benefits which is particularly significant to youths.

\section{Literature Review}

The contribution of youth to national development has been acknowledged, as they form bulk of the labour force required in all sectors of the economy. However, this contribution could only be possible if the youths acquire the necessary skills, through vocational training to fit in 
properly in the job vocations or alternatively become self-reliant and employers of labour. Advocates of skills acquisition believed that it would reduce joblessness and unemployment which majority of them are experiencing. Regrettably, the youths appear not interested, hinging their argument on lack of social infrastructure as a catalyst in skills acquisition and making use of the skills acquired. They complained lack of electricity, good transportation among others. The question is, are social infrastructure critical to vocational skill acquisition and practice? An attempt to answer this question makes a study of this nature necessary.

The main purpose of the study is to examine the perceived influence of socio-economic infrastructure on vocational skills acquisition and practice among rural youths in Bonny Local Government Area. The study intends to: (1) Identify the vocational skills extended to Bonny Youths in Bonny Local Government Area; (2) Determine the influence of transportation on vocational skills acquisition and practice among youths in Bonny Local Government Area; (3) Determine the influence of electricity on vocational skills acquisition and practice among youths in Bonny Local Government Area; (4) Determine the influence of market on vocational skills acquisition and practice among youths in Bonny Local Government Area.

The following null hypotheses were postulated and tested at 0.05 level of significance.

1. There is no significant difference in the mean responses of male and female youths on the vocational skills extended to them in Bonny Local Government Area

2. There is no significant difference in the mean responses of male and female youths on the influence of transportation on their vocational skills acquisition and practice in Bonny Local Government Area

3. There is no significant difference in the mean responses of male and female youths on the influence of electricity on their vocational skills acquisition and practice in Bonny Local Government Area

\section{Research Method}

The study adopted a descriptive survey research design. The population of the study consist of all rural youths in the 34 chieftaincy houses that made up Bonny Local Government Area which according to the National Bureau of Statistics (2006) is a total of 78,373. The sample size was 398 youths sampled from the population using Taro Yamen sample determination model. To select sample, multi-stage sampling techniques was adopted. Firstly, Bonny Local Government Area was clustered into 34 chieftaincy houses. Secondly, 11 burusus were randomly sampled from each chieftaincy house giving a total of 374 burusus. Thirdly, 1 respondent was selected from each burusu giving a total of 374 burusus while an addition of 24 respondents were selected from the major houses giving a total sample size of 398 used for the study. The instrument used for the research was a structured questionnaire designed to elicit responses to answer the research questions. A Likert five point rating scale of High Influence (HI), Moderate Influence (MI), Undecided (U), Low Influence (LL), Very Low Influence (VLI) was used for the research questions. In order to validate the instrument, the questionnaire was given to three experts who extensively carried out face and content validity relating to the appropriateness of the content of the questionnaire which was used for the study. In order to establish the reliability of the instrument, the validated instrument was tested using 30 respondents (rural youths) selected from non Ibani (Bonny) speaking area. Data collected were analyzed using Cronbach Alpha to determine the internal consistency of the items. This gave the overall reliability coefficient value of 0.70 for the instrument indicating that the instrument is reliable and therefore appropriate for the study. The instruments were personally administered to the respondents 
alongside two other trained research assistants. Mean and standard deviation were used to answer the research questions while z-test was used to test the hypotheses at 0.05 level of significance. Mean values less than 3.00 was rejected while mean values greater than or equal to 3.00 was accepted. The data were analyzed with the aid of SPSS 20.0 version and excel software.

\section{Findings and Discussions}

The findings in research question 1 revealed that the male and female youths in Bonny Local Government Area believe there are vocational skills extended to them, such as provision of quality catering services, welding, hair dressing, dress making, pipe fitting, soap making, sandblasting \& spray painting, out-sourced business services, bead making, electrical \& instrumentation, decoration of wedding venue and shoe making.

Also result in hypothesis one indicates that there is no significant difference in the mean responses of male and female on the vocational skills extended to them in Bonny Local Government Area. The findings is in agreement with Okwelle and Deebom (2017) who in their study noted that youths are fully aware that there is vocational skills training as well as its benefits in national development.

From the finding in research question 2, all the respondents agreed that transportation influences their vocational skills acquisition and practice in Bonny Local Government Area.

The hypothesis testing in research question 2 equally indicates that there is no significant difference in the mean responses of male and female youths on the influence of transportation on their vocational skills acquisition and practice in Bonny Local Government Area. The finding $\mathrm{s}$ is in line with Aminu (2015) who noted that adequate rural roads could influence socioeconomic development such as transportation in rural areas.

Respondents from the findings in research question 3 agreed that electricity influences their vocational skills acquisition and practice in the study area.

The hypothesis testing in research question 3 showed that there is no significant difference in the mean responses of male and female youths on influence of electricity on their vocational skills acquisition and practice in Bonny Local Government Area. The findings is in agreement with Foluke (nd) who in her study noted that vocational skills acquisition programmes are designed to enhance the skills and knowledge of youths for immediate employment whether in the private or public sector or be self employed. Similarly, Omotara (2012) argued that rural development would only be possible when physical inputs like electricity are provided in the areas concerned.

Respondents from the findings in research question 4 agreed that market influences their vocational skills acquisition and practice in the study area. The findings agreed with those of Ambakaderemo \& Kalu (2018) who noted that markets help in the enhancement of vocational skills acquisition and practice by bringing together people of divergent culture and religion for social interaction as well as promoting inter-communal harmony which by extension promotes peace and development.

Table 1. $\mathrm{z}$ test of difference between male and female youths on the vocational skills Extended to Bonny youths in Bonny Local Government Area. 


\begin{tabular}{|c|c|c|c|c|c|c|c|}
\hline Rural Youths & M & SD & df & Z-cal & Z-crit & Remarl & \\
\hline \multirow[t]{2}{*}{ Male } & 214 & 2.98 & 0.88 & & & & \\
\hline & & & & 396 & 2.00 & 1.96 & Accepted \\
\hline Female & 184 & 2.89 & 1.09 & & & & \\
\hline
\end{tabular}

Table 1 revealed that there is no significant difference in the mean responses of male and female youths on the influence of electricity on their vocational skills acquisition and practice in Bonny Local Government Area. The calculated $Z$ value of 1.00 is less than the $Z$ critical of 1.96 at 0.05 level of significance leading to the acceptance of the hypothesis.

H02: There is no significant difference in the mean responses of male and female youths on the influence of transportation on their vocational skills acquisition and practice in Bonny Local Government Area.

Tablen 2. z-test difference between male and female youths on the influence of transportation on their vocational skills acquisition and practice in Bonny Local Government Area.

\begin{tabular}{llllllll}
\hline Rural Youths & $\mathrm{N}$ & $\mathrm{M}$ & $\mathrm{SD}$ & $\mathrm{df}$ & Z-cal & Z-crit & Remark \\
\hline Male & \multirow{2}{*}{214} & 2.96 & 0.79 & & & & \\
& & & & 396 & 2.00 & 1.96 & Accepted
\end{tabular}

Female

$\begin{array}{lll}184 & 2.84 & 1.05\end{array}$

Table 2 showed that there is no significant difference in the mean responses of male and female youth on the influence of transportation on their vocational skills acquisition and practice in Bonny Local Government Area. The Calculated $\mathrm{Z}$ value of 1.00 is less than the $\mathrm{Z}$ critical of 1.96 leading to the acceptance of the hypothesis.

Ho3: There is no significant difference in the mean responses of male and female youths on the influence of education on their vocational skills acquisition and practice in Bonny Local Government Area.

Table 3. z-test difference between male and female youths on the influence of electricity on their vocational skills acquisition and practice in Bonny Local Government Area.

\begin{tabular}{llllllll}
\hline Rural Youths & $\mathrm{N}$ & $\mathrm{M}$ & $\mathrm{SD}$ & $\mathrm{df}$ & Z-cal & Z-crit & Remark \\
\hline Male & 214 & 2.93 & 1.06 & & & & \\
& & & & 396 & 2.00 & 1.96 & Accept \\
Female & 184 & 2.83 & 1.11 & & & & \\
\hline
\end{tabular}

Table 3 revealed that there is a significant difference in the mean responses of male and female youths on the influence of electricity on their vocational skills acquisition and practice in Bonny Local Government Area. The $\mathrm{Z}$ calculated value of 2.00 is greater than the $\mathrm{Z}$ critical of 1.96 at 0.05 level of significance leading to acceptance of the hypothesis.

\section{Conclusion}

From the findings, it was deduced that male and female youths in Bonny Local Government Area agreed that there are vocational skills training in Bonny Local Government Area,. findings 
also revealed that youths in Bonny Local Government Area agreed that transportation influences their acquisition of vocational skills. Similarly, findings, revealed that electricity influences vocational skills acquisition and practice among youths in Bonny Local Government Area, finally, youths in Bonny Local Government Area agreed that market influences their vocational skills acquisition and practice.

\section{References}

Ambakaderemo, B., \& Kalu, E. (2018). Rural Markets and Nigeria's Economic Development: A Case Study of Selected Markets in Bayelsa State. International Journal of Advanced Academic Research, Social and Management Sciences 4 (4),16-28.

Aminu, A. A. (2015). Influence of Rural Roads on the Patronage of Rural Markets in Kadau Local Government Area, Kaduna State. unpublished Dissertation, Ahmadu Bello University Zaria, Nigeria.

Anaele, E. O. (2018). Vocational Skills Acquisition Leveraging: Unemployment, Social Vices, Insecurity and Technological Retardation for Sustainable Development in Nigeria. Book Of Proceedings for $3^{\text {rd }}$ Annual Conference of the Faculty of Vocational \& Technology Education, Ignatius Ajuru University of Education, Rumuolumini, Port Harcourt.

Dada, J. (2007). Small-Scale Business Enterprises Available in Clothing and Textile Education For Economic Empowerment of the Family. Journal of Home Economics Research, 8, 174-175. Foluke, F. (nd). Effectiveness of Vocational Skills Acquisition Programme on Women Empowerment: National Open University of Nigeria as Case Study. National Open University of Lagos.

Goel, D. (2002). Impact of Infrastructure on Productivity: Case of Indian Registered Manufacturing: Shri Ram College of Commerce. Working Paper No. 106.

Igwe, E. B. \& Oragwu, A. A. (2014). Techo-Vocational Sills Acquisition and Poverty Reduction Strategies on Vocational Institutions; the case of Rivers State. African Journal of Educational Technology, 4(1), 47-5.

Industrial Training Fund (2014). An Appraisal of Skill Acquisition Centres in Nigeria. Jos. Research \& Curriculum Development Department.

Inyang, M. N. \& Agwadu, D. K. (2017). Empowering the Rural Poor through Vocational Skills Acquisition: Nasarawa State in Focus. International Journal of Development And Sustainability, 6(3), 115-129.

Kabiru, S. A. (2016). Socio-Economic Infrastructure and National Development: An Analytical Assessment from Nigerian Perspective. Journal of Humanities and Social Sciences, 21(10),3642.

Lawal, A. W. (2014). Teachers and Vocational Education, A Tool for National Development in Nigeria. International Journal of Social and Humanities Sciences, 14(1), 53-59.

Nwafor, S. (2018). Vocational Skills Acquisition in Agriculture Leveraging: Unemployment, Social Vices, Food Insecurity and Technological Retardation for Sustainable Development in Nigeria. Book of Proceedings for $3^{\text {rd }}$ Annual Conference of the Faculty Of Vocational \& Technical Education, Ignatius Ajuru University of Education, Rumuolumeni, Port Harcourt. Ojingwa, A. (2018). Vocational Skills Acquisition in Technical learning. Unemployment, Social Vices, Food Insecurity and Technological Development in Nigeria. Book of Proceedings For $3^{\text {rd }}$ Annual Conference of the Faculty of Vocational and Technical Education, Ignatiu Ajuru University of Education, Port Harcourt.

Okoye, A. C. (2017). Entrepreneurship Education: A Panacea for Graduate Unemployment in Nigeria. Online Journal of Arts, Management \& Social Sciences, 2(1). 
Okwelle, P. \& Deebom, T. M. (2017). Technical Vocational Education and Training as a Tool for Sustainable Empowerment of Youths in Niger Delta, Nigeria. International Journal of Innovative Studies \& Science Education Research, 5(1),29-38.

Omotara, O.A. (2012). Effect of Rural Infrastructure on Social Well-being of Farmers in Ifedayo Local Government Area of Osun State. Nigeria. Nigerian Journal of Rural Sociology 13(2), 55-62.

Revermann, S. (2015). What is the Difference Between Vocational \& Technical Courses? Education by Demand Media. Retrieved on $7^{\text {th }}$ November 2019 from http://education. Seattlepi.com/difference.between-vocational-technical-courses-3063html.

Thomas, C. G. \& Amaechi, O. (2016). The Relevance of Technical and Vocational Skills Acquisition Programme in the Development and Empowerment of Rural Youths in Niger Delta Region, Nigeria. Journal of Scientific and Engineering Research 3(6),473-478.

Zayyard, M. (2018). So, Nigeria is World's Poverty Capital? Vanguard Newspaper, July 2, 2018. Retrieved from http://www.vanguardngr.com/2018/06/nigeria-overtakes-india-asWorlds-poverty-capital-report.

\section{Copyrights}

Copyright for this article is retained by the author(s), with first publication rights granted to the journal.

This is an open-access article distributed under the terms and conditions of the Creative Commons Attribution license (http://creativecommons.org/licenses/by/4.0/) 